\title{
NUMERICAL EXAMINATION OF THE INFLUENCE OF HEADREST USE ON THE BODY OF A SOLDIER IN A VEHICLE LOADED WITH A 25 KG SIDE LOAD
}

\author{
NUMERYCZNE BADANIE WPŁYWU ZASTOSOWANIA ZAGŁÓWKA \\ NA CIAŁO ŻOŁNIERZA ZNAJDUJĄCEGO SIĘ \\ W POJEŹDZIE OBCIĄŻONYM ŁADUNKIEM BOCZNYM 25 KG*
}

\begin{abstract}
The issue of specialist vehicle crews' impulse resistance is described in many articles and standardization documents. These publications concern mainly explosives of smaller size. In case of sizeable explosives between 25 and $1000 \mathrm{~kg}$, specialist literature is very poor. In most cases, the existing literature presents the influence of an explosive placed under the vehicle's wheel or body. The following paper focuses on the influence of a $25 \mathrm{~kg}$ charge placed on the side of the vehicle on the organism of a soldier staying inside. In this paper the numerical analysis results of the vehicle-explosion mechanical system have been presented. The explosion has 1 been modeled using the CONWEP function. The numerical analysis has been carried out in LS-DYNA software. The vehicle has been described by Lagrange elements. The article presents results of numerical calculations for the elements of a combat vehicle's bearing structure charged with an impact generated by an explosion of a big charge placed to the side of the vehicle, at the distance of $5 \mathrm{~m}$ from the sideboard, at the height of $1 \mathrm{~m}$. Unfortunately, the method used does not allow for taking into account the phenomena occurring as a result of the wave reflecting off the ground.
\end{abstract}

Keywords: specialist vehicle, explosion, vehicle's movement, FEM analysis.

\begin{abstract}
Problematyka odporności udarowej zatóg pojazdów specjalnych jest opisywana $w$ wielu artykułach $i$ dokumentach standaryzacyjnych. Publikacje te głównie dotycza małych wielkości ładunków wybuchowych oddziałujących na pojazd. W przypadku dużych ładunków, o wielkości od 25 do $1000 \mathrm{~kg}$, literatura tematu jest bardzo uboga. Istniejace pozycje literaturowe odnosza się do oddziaływania ładunku umieszczonego pod kołem lub kadlubem pojazdu. W pracy przedstawiono wpływ wielkości ładunku 25 $\mathrm{kg}$ umieszczonego z boku pojazdu na organizm żotnierza znajdującego się w nim. Przedsięwzięcie to zrealizowano za pomoca analizy numerycznej układu mechanicznego pojazd-wybuch. Wybuch został zamodelowany funkcja CONWEP. Numeryczna analize przeprowadzono przy użyciu oprogramowania LS-DYNA. Pojazd zostat opisany elementami Lagrange'a. W artykule przedstawiono wyniki obliczeń numerycznych elementów struktury nośnej wozu bojowego obciązonej udarem wygenerowanym przez eksplozję dużego tadunku wybuchowego umieszczonego z boku w odległości $5 \mathrm{~m}$ od burty pojazdu na wysokości $1 \mathrm{~m}$. Zastosowana metoda nie pozwala na uwzględnienie zjawisk Macha zachodzących podczas odbicia fali od podłoża.
\end{abstract}

Stowa kluczowe: pojazd specjalny, wybuch boczny, analiza MES.

\section{Introduction}

Specialist vehicles are exposed to the effects of multiple weapons at enemy's disposal, mainly improvised explosive devices (IED). It results in the fact that contemporary tactical-technical requirements indicate methods of forming military vehicles' armoured bodies in order to provide the crews' high survival capability on the battlefield. Such activities are connected, among others, to providing proper level of protection against mines of different categories (various explosive materials, different masses, various explosive location).

The fundamental issue appears while creating effective crew and internal equipment protection against mines $[1,2]$, and especially against improvised explosive devices which may contain explosive charges of considerable sizes.

So far, a significant amount of research on human survivability has been conducted. The main driving force behind progress in this domain has been aviation. Military activities in irregular conflicts cause the enemy to make use of materials which are called improvised explosive devices due to their classification method. They may have local or global effect on a vehicle, depending on their size.

In case of an explosion having effect on a vehicle, the results may be classified as:

- knocking the vehicle over [3],

- tossing the vehicle into the air (the crew is affected during both raising and falling) [2, 5],

- armour penetration,

- membrane wave appearance $[4,5]$.

The main factor of the explosion's impact on the crew is acceleration. The explosion (pressure impulse) affecting the side of a vehicle through construction elements such as seat base or the body (floor) causes perpendicular and longitudinal angular, as well as transverse

(*) Tekst artykułu w polskiej wersji językowej dostępny w elektronicznym wydaniu kwartalnika na stronie www.ein.org.pl 
angular accelerations which affect the soldier remaining inside the vehicle. The most exposed to these accelerations are bone structure elements, such as tibias, spine (fragments around pelvis and cervical vertebrae). Research on biomechanical resistance of a human body is being carried on, focusing on many aspects, from car accidents through aviation accidents through explosive charges explosions [6, $7,10,12-17]$. Such research is being conducted virtually all over the world.

In case of lack of seatbelts (or not fastening them) there exists strong likelihood of head injury against the vehicle ceiling. Such impact may result in injuring cervical vertebrae [13].

Human organism's response has been examined, among others, by Patrick, Kroell and Mertz [9], who concluded that the human organ exposed to G-force damage the most is brain. The authors have demonstrated a relationship between impulse size and its duration.

The following paper focuses on the impact side charges exert on vehicle, or rather on human body. The paper presents results of explosive charges influence on specialist vehicles crews. Additionally, the influence of the headrest used on human body response has been examined.

\section{Numerical models description}

Usually, in examining soldiers behaviors in armored vehicles LS-Dyna or MSC Dytran software is used. These programs contain explicit implementation of finite element method. They allow for modeling complex phenomena from the range of classical mechanics, flux mechanics, dynamic phenomena, as well as strong discontinuities impact on various structures. For the calculation purposes, Hybrid Dummy III 95\% Male [11] model, presented in Fig. 1 has been used. The model had been developed and examined mainly for the purposes of automobile industry. It is used in research on increasing the safety of drivers, passengers, as well as car accident participants.

As has been mentioned before, Hybrid III dummies are used to simulate humans. Thanks to their build, resembling one of a man, the analysis of the results obtained gives full picture of the probability of sustained injuries.

In his book of 1964, J. Grzegorzewski [6] demonstrated that acceleration of $100 \mathrm{~g} / 2 \mathrm{~ms}$ is lethal. This value was increased to $150 \mathrm{~g} / 2 \mathrm{~ms}$ by Allem in his 1996 research. The juxtaposition of body injury cases based on the duration is presented in Table 1.

Practically, survivability indexes described in AEP-55 are not exactly indicators. They are defined values created as a result of research on survivability.

Additional research work in NATO [13] concerned tibia injuries resulting from axial force impulse's influence on tibiasin the aspect of age of soldiers exposed to the load. The research has indicated that due to ca. $9 \mathrm{kN}$ axial force influence, the likelihood of injuries for people at the age of 65 amounts to $100 \%$, to $90 \%$ for 45 -year-olds, and in case of 25 -year-olds it decreases down to $25 \%$.
The following paper includes the results of initial numerical analysis of an explosion of a large, side IED charge on a specialist vehicle crew member. In the analyses carried out, a wheeled vehicle of ca. 22 tons has been assumed as the subject of study. The IED charge was placed at the distance $\mathrm{X}$ of $5 \mathrm{~m}$ from the vehicle, at the height $\mathrm{H}$ of 1 $\mathrm{m}$ over the ground, as presented in Fig. 2.

Lagrange elements of Shell Quad 4 type were used to model the behavior of vehicle's steel sheets. The elements were given the following mechanical properties: $\mathrm{E}=2.1 \cdot 10^{9} \mathrm{MPa}, v=0.31$. For the description of steel behavior a bilinear elastoplastic model was used. Maximal deformation [10] was assumed as the damage criterion. A general view of vehicle numerical model, as well as the section of the whole layout is presented in Fig. 3. Both the seat with Hybrid 3 dummy and the fastening method are presented in figures below.

Numerical analyses examined two models differing according to the use of headrest (model 1 without any headrest, model 2 with a headrest). For numerical analyses of impulse effect on a crew member Hybryd III dummy was used. The dummy model - 50-centile Hybrid III, implemented separately from vehicle model by LS-DYNA system. The dummy was situated on an inflexible seat with afootrest and

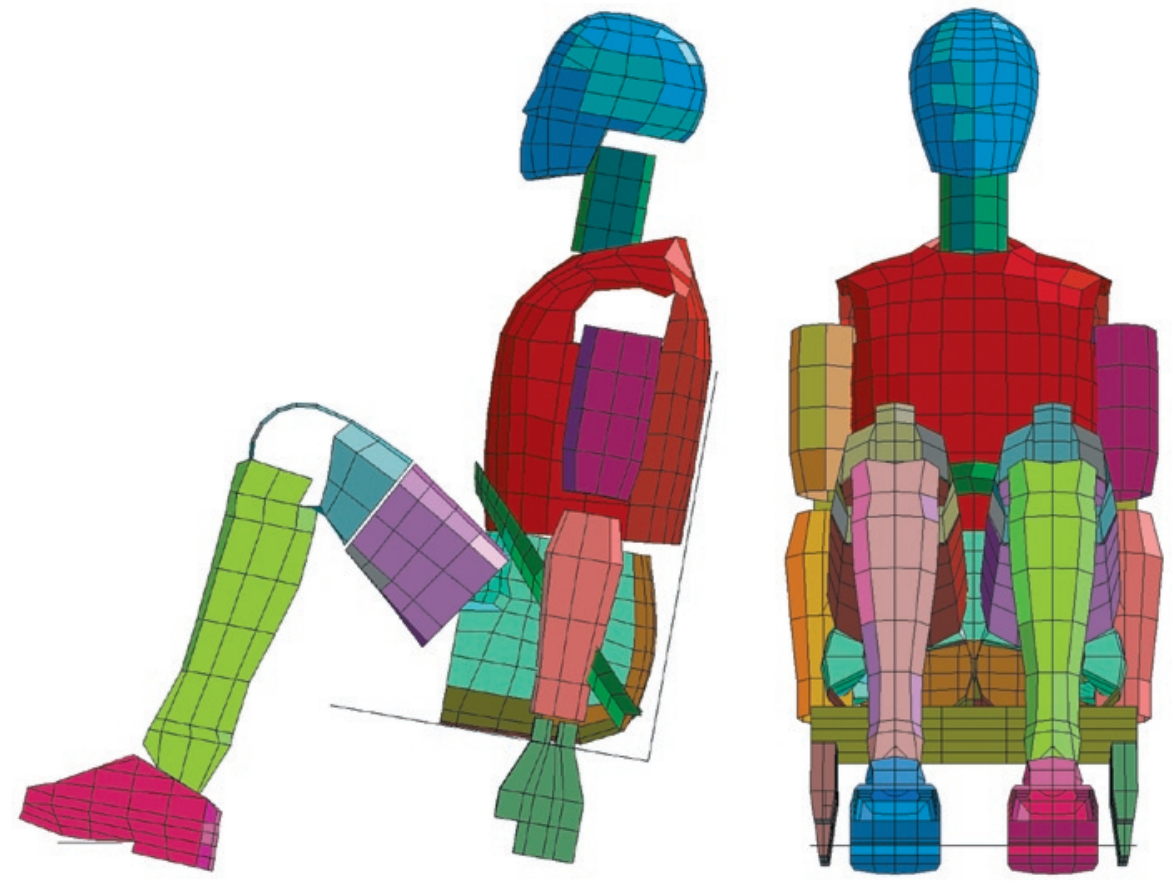

Fig. 1. Hybrid III dummy model

pelvic seat belts.

Table 1. Survivability index according to AEP-55 [12]

\begin{tabular}{||c|c|c|c|c||}
\hline No. & Body part & Criterion & $\begin{array}{c}\text { Permissible } \\
\text { value }\end{array}$ & gravity (significance) \\
\hline 1. & tibia & maximal tibia clenching force value (-Fz) & $5.4 \mathrm{kN}$ & $10 \%$ risk for ASI 2+ \\
\hline 2. & $\begin{array}{c}\text { thoracic-lumbar } \\
\text { region }\end{array}$ & $\begin{array}{c}\text { Dynamic Response Index (DRI)established } \\
\text { based on pelvis acceleration Az }\end{array}$ & 17,7 & $10 \%$ risk for ASI 2+ \\
\hline \multirow{2nnyyy}{*}{3.} & $\begin{array}{c}\text { cervical region } \\
\text { (neck) }\end{array}$ & $\begin{array}{c}4 \mathrm{kN} \\
\text { upper neck section clenching force (-Fz) }\end{array}$ & $\begin{array}{c}1.1 \mathrm{kN}(\text { during } \\
30 \mathrm{~ms} \text { ) }\end{array}$ & $\begin{array}{c}\text { Serious (ASI 3) injuries } \\
\text { are unlikely }\end{array}$ \\
\cline { 3 - 6 } & & $\begin{array}{c}\text { upper neck section crushing moment } \\
\text { bending (+My) } \\
\text { stretching (-My) }\end{array}$ & $\begin{array}{c}190 \mathrm{Nm} \\
77 \mathrm{Nm}\end{array}$ & $\begin{array}{c}\text { Serious (ASI 2) injuries } \\
\text { are unlikely }\end{array}$ \\
\hline 4. & internal organs & Central Venous Pressure (CVP) & $3.6 \mathrm{~m} / \mathrm{s}$ & \\
\hline
\end{tabular}




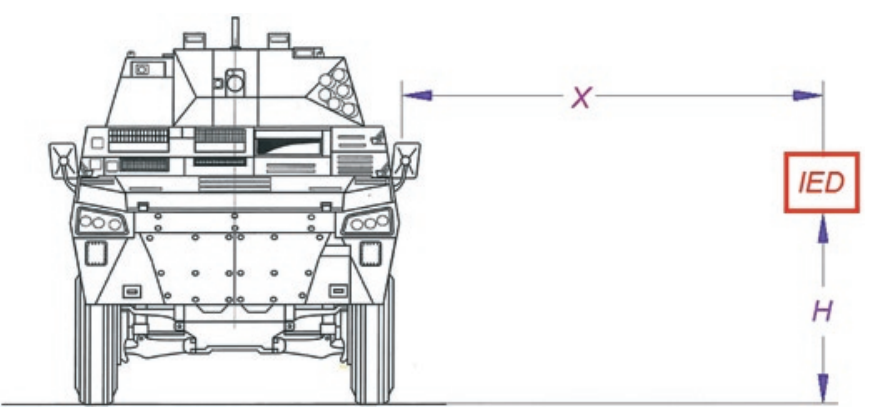

Fig. 2. Charge placement diagram relative to vehicle body

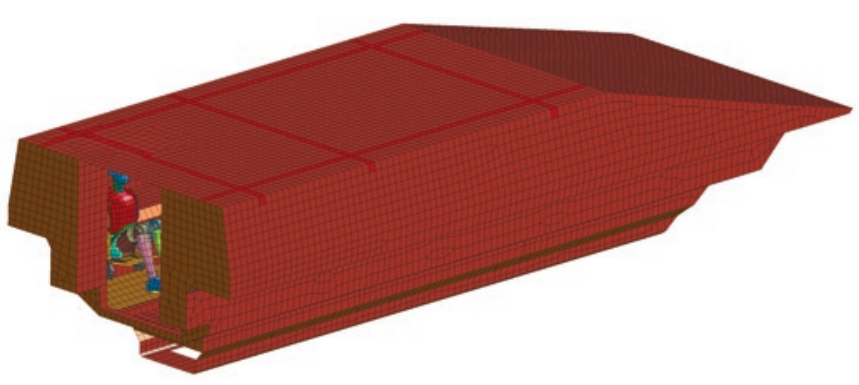

Fig. 3. Numerical vehicle model with a crew member

During numerical analyses, gravity's effect on the numerical model was taken into account.

All military armored vehicle tests are conducted according to appropriate norm, in this case NATO SATANG 4569. One of possible anti-mine resistance tests is examining the effects of TM 57 anti-personnel mine detonation with a $6.34 \mathrm{~kg}$ TNT charge. Due to the need for protection against IEDs, whose mass substantially exceeds the one of anti-personnel mines, the analysis conducted focused on a vehicle model loaded with an IED of significantly bigger mass than TM 57 mine.

\section{Numerical analyses results}

\subsection{Numerical analyses results $-25 \mathrm{~kg}$ charge without headrest}

As a result of the explosion, there appeared pressure wave impact on the side of the vehicle. Fig. 4 presents subsequent phases of vehicle's body movement under the effect of a $25-\mathrm{kg}$ TNT charge.

The dummy's head's movement backwards (especially clearly visible in Fig. 4b), which can damage a soldier's neck is worth mentioning. This movement is caused by the lack of headrest. Additionally, the explosive moved the whole vehicle. Asymmetrical displacement was caused by the vehicle body's asymmetry and the explosive's placement outside of center of gravity.

Analyzing Figs. $4 a-d$ it is worth noticing that Hybryd III's back broke away from the seat. The breaking away took place despite the seat belt use.

The main injury likelihood assessment is conducted as a result of the analyses of physical value course in time, presented in charts below (Figs. 5-8). The maximal values of quantities measured are additionally presented in Table 2 .

The way of loading the vehicle entails different effect on a crew member than it has been so fat. Generally, vehicles were examined in the aspect of a load resulting from an explosion of a charge placed under a wheel or centrally. In the case in question, tibia clenching force value equals ca. $141 \mathrm{~N}$ (Fig 5.)

In the case in question, the value of maximal pelvis acceleration in vertical direction equaled $3.7 \mathrm{~g}$ (Fig. 6). a)
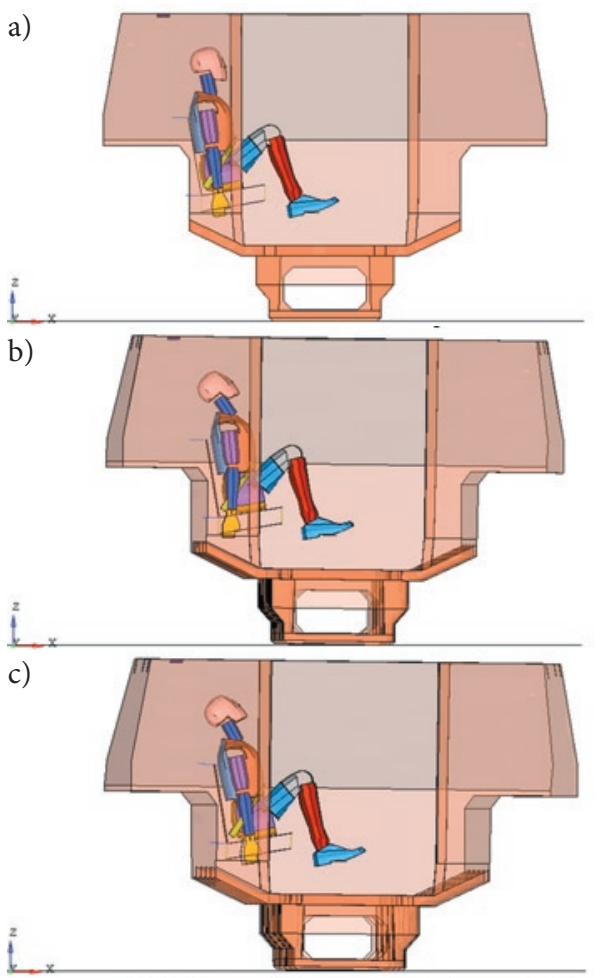

d)

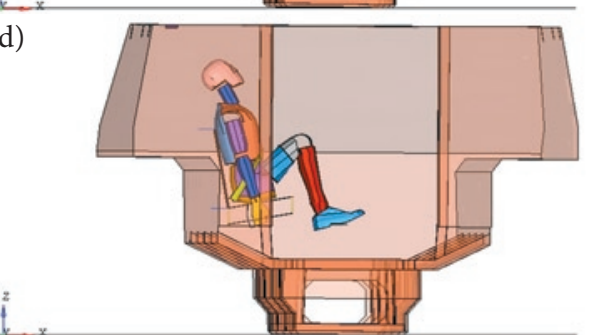

$25 \mathrm{~kg}$ TNT Wybuch $\mathbf{z}$ boku pojazdu Time $=0.300484$

Fig. 4. The manner of vehicle body deformation and explosion's effect on a dummy in different time periods: a) $0 \mathrm{~s}$, b) $0.2 \mathrm{~ms}$, c) $0.25 \mathrm{~ms}$, d) $0.3 \mathrm{~ms}$

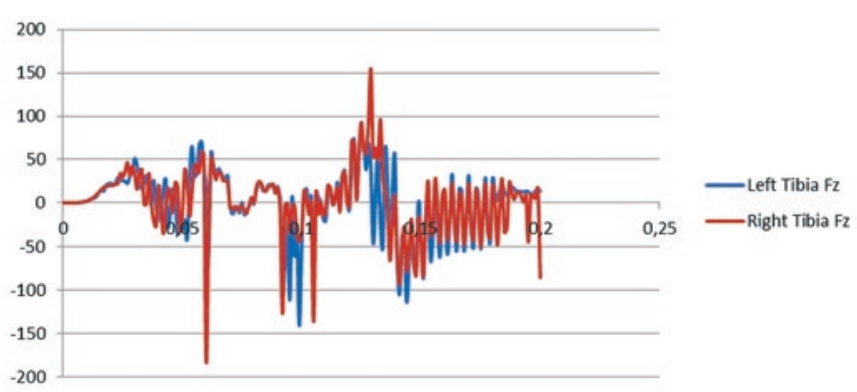

Fig. 5. Chart of longitudinal force in both tibias axis $Y$ [N] axis $X$ [ms]

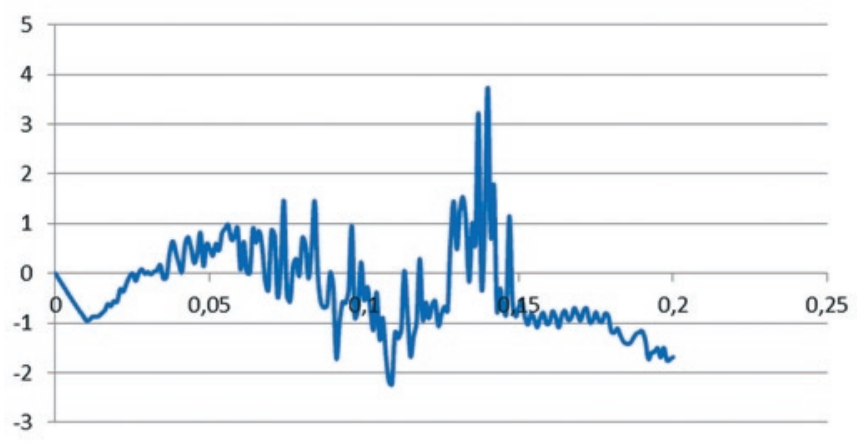

Fig. 6. Pelvis acceleration chart in vertical direction axis $Y$ [N] axis X [ms] 


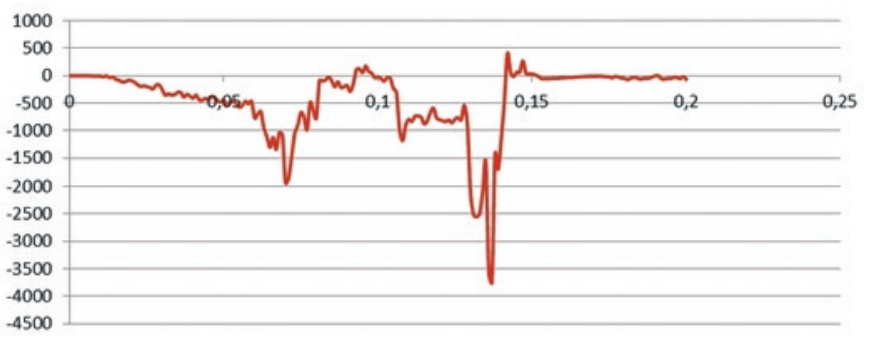

Fig. 7. Chart of longitudinal force in the spine axis $Y$ [N] axis X [ms].

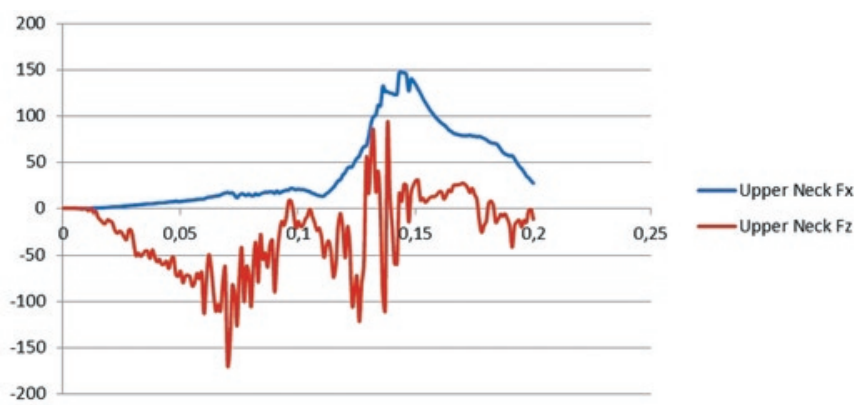

Fig. 8. Chart of longitudinal and transverse forces in the neck axis $Y$ [N] axis $X[\mathrm{~ms}]$

Similarly to accelerations in the spine, the value of longitudinal force in the spine does not amount to critical quantities and equals $3750 \mathrm{~N}$ (Fig. 7).

Of interest is the chart of forces in the neck. Practically, the values may differ from the ones obtained due to the fictitious force closely related to the system mass. In a real vehicle, a soldier wears a helmet (which may weigh several kilograms with additional gear).

Compared to force values in lower limbs, maximal elongation force value $\mathrm{Fz}$ equaled $168 \mathrm{~N}$, and transverse force (shear) Fx $150 \mathrm{~N}$.

\subsection{Numerical analyses results $-25 \mathrm{~kg}$ charge with headrest}

In the model in discussion, additional headrest placed at the back of the vehicle was used. Similarly to the first model, as a result of the explosion there appeared pressure wave affecting the side of the vehicle. Fig. 9. presents subsequent phases of vehicle's body movement (with a headrest mounted to the seat) under the effect of a $25-\mathrm{kg}$ TNT charge.

Compared to the previous model, there has been no backwards deviation of the soldier's head. The use of headrest prevented back of the head's relocation (Fig. 4b). Similarly to the first model, the explosive moved the whole vehicle. Asymmetrical displacement was caused by the vehicle body's asymmetry and the explosive's placement outside of center of gravity.

Analyzing Figs. 9. it is worth noticing that the back of Hybryd III dummy broke away from the seat, as in the first case. The breaking away took place despite the seat belt use.

The main injury likelihood assessment is conducted as a result of the analyses of physical value course in time, presented in charts below (Figs. 10-13). The juxtaposition of maximal values of quantities measured are additionally presented in Table 2 .

The way of loading the vehicle entails different effect on a crew member than it has been so fat. Generally, vehicles were examined in the aspect of a load resulting from an explosion of a charge placed under a wheel or centrally. It resulted in large values of forces and perpendicular accelerations, affecting a person.

In the case in question, tibia clenching force value equals ca. 262 N (Fig 10.)

In the case in question, the value of maximal pelvis acceleration in vertical direction equaled $6.2 \mathrm{~g}$ (Fig. 11).

Similarly to the accelerations in the spine, the value of longitudi-

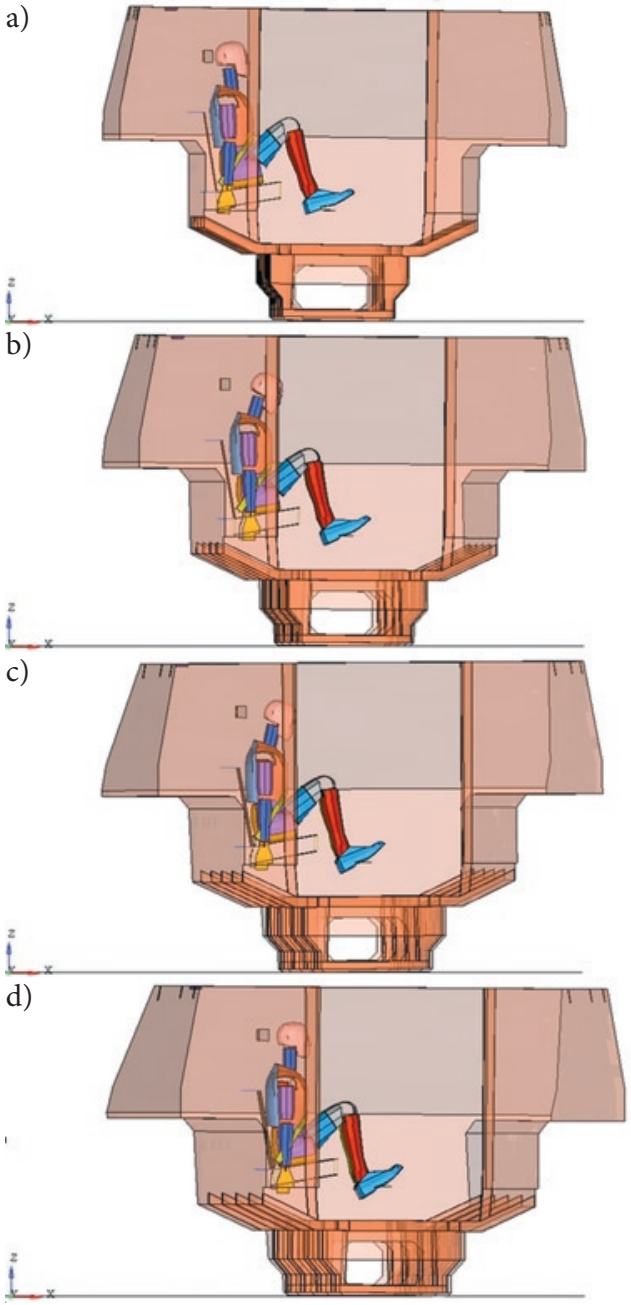
$25 \mathrm{~kg}$ TNT
Wybuch z boku pojazdu
Time $=0.199998$

Fig. 9. The manner of vehicle body deformation and explosion's effect on a dummy in different time periods: a) $0.2 \mathrm{~ms}$, b) $0.3 \mathrm{~ms}$, c) $0.4 \mathrm{~ms}$, d) $0.5 \mathrm{~ms}$.

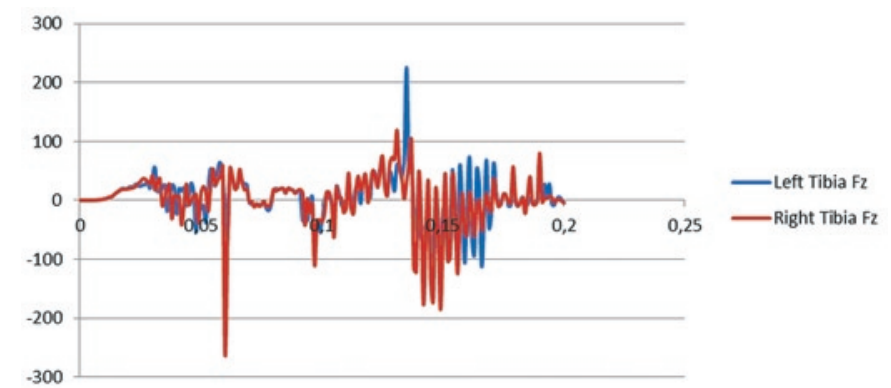

Fig. 10. Chart of longitudinal force in both tibias for the case with a headrest used axis $Y[N]$ axis $X[m s]$.

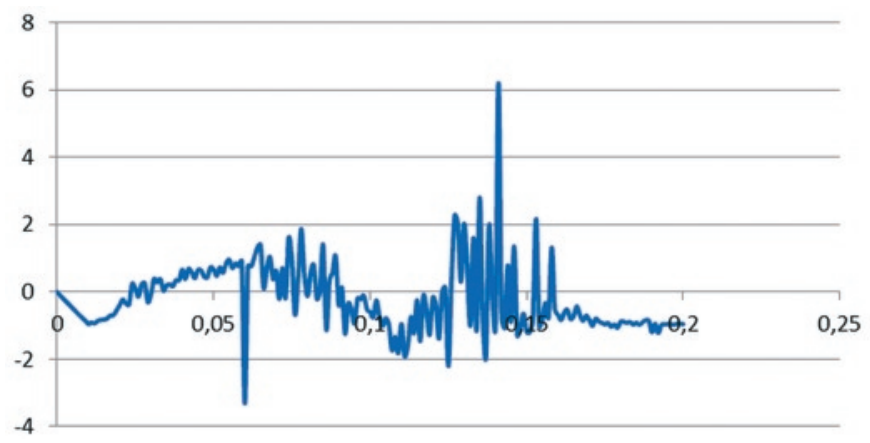

Fig. 11. Pelvis acceleration chart in vertical direction axis $Y$ [N] axis X [ms] 


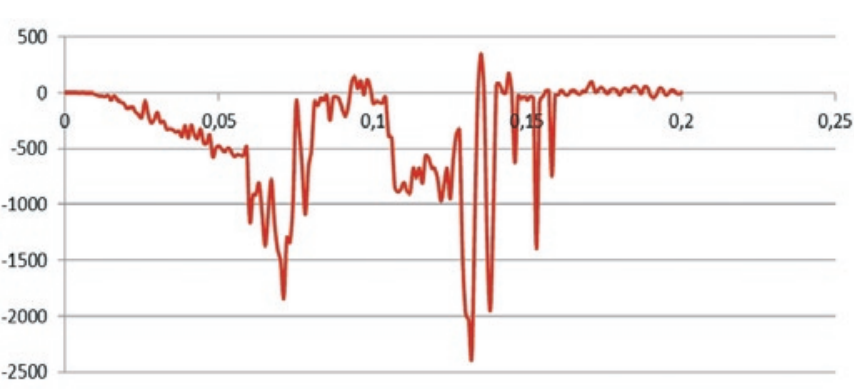

Fig. 12. Chart of longitudinal force in the spine axis $Y$ [N] axis X [ms]

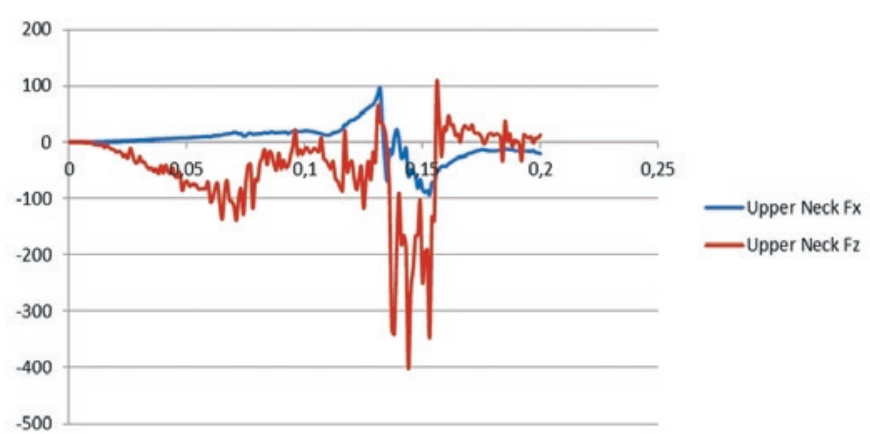

Fig. 13. Chart of longitudinal and transverse forces in the neck axis $Y$ [N] axis $X[m s]$

Table 2. Maximal values from acceleration and force courses.

\begin{tabular}{|c|c|c|c|c|c||}
\hline & Pelviz Z acceleration [g] & Lumbar Fz [N] & Upper Neck Fz [N] & $\begin{array}{c}\text { Upper Neck Fx [N] } \\
\begin{array}{c}\text { Tibia R } \\
\text { Fz [N] }\end{array}\end{array}$ & $\begin{array}{c}150 \\
\text { Fz [N] }\end{array}$ \\
\hline 25 kg ref. & 3,7 & -3750 & -168 & -141 \\
\hline 25 kg protection & 6,2 & -2360 & -400 & 100 \\
\hline
\end{tabular}

nal force in the spine does not reach critical quantities and equals $2360 \mathrm{~N}$ (Fig. 12). It is worth noticing that the use of headrest contributed to decreasing the value of this force.

As in the previous case, of interest is the chart of forces in the neck. Practically, the values may differ from the ones obtained due to the fictitious force closely related to the system mass. In a real vehicle, a soldier wears a helmet. Compared to force values obtained for the first model, a significant decrease in transverse (shear) force Fx $100 \mathrm{~N}$ was noted. Unfortunately, the use of headrest strengthened the effect of elongation force $\mathrm{Fz}$, which equaled $400 \mathrm{~N}$.

\section{Conclusions}

The article presents one fragment of the analysis of specialist vehicles soldier's protection. Scientific papers to date have not included side influence of large explosives on crew members. The use of finite-element method for numerical analyses allows for limiting the duration of construction process. One should not forget that obtaining satisfactory results does not absolve the constructors of critical approach to the results obtained. Additionally, it is worth noticing that some quantities used to assess the value of human survivability were exceeded. It entails the necessity of modifying the way in which landing forces soldiers are seated.

Proper placement of the explosive charge relative to the vehicle may cause the appearance of numerous unfavorable phenomena from the vehicle protection point of view. In the case of incorporating explosive border value, a knocking over or tossing the vehicle into the air may take place.

\section{Acknowledgement}

This study has been supported by the National Centre for Research and Development as a part of a research \& development project No DOBBiO/001/05/2014. This support is gratefully acknowledged.

\section{References}

1. AEP-55, Volume 2 for mine threat (Edition 1). Procedure for evaluating the procetion level of logistic and light armoured vehicles, NATO/ PfP Unclassified publication 2006.AEP 55, Wydawnictwo NATO,

2. Barnat W. Badania symulacyjne pojazdów wojskowych. Wydawnictwo Wojskowego Instytutu Techniki Inżynieryjnej we Wrocławiu 2014; 241-269.

3. Barnat W. Numerical and experimental investigation on internal membrane pressure wave inside sealed structure. Bulletin of the Polish Academy of Sciences - Technical Sciences 2013; 61, 3; 613-621, http://dx.doi.org/10.2478/bpasts-2013-0064.

4. Barnat W. Wybrane zagadnienia ochrony życia i zdrowia załóg pojazdów przed wybuchem. Military Rok 2011.

5. Barnat W., Nawrat A. The influence the location of large charge on behaviour special vehicles SHIBA and AV (Armoured Vehicle). Studies in Systems, Decision and Control 2, Innovative Control Systems for Tracked Vehicle Platforms, Aleksander M. Nawrat (ed.). Wyd. Springer 2014.

6. Grzegorzewski J. Przyśpieszenia, przeciążenia, nieważkość. Wydawnictwo MON 1964.

7. Krzystała E., Kciuk S., Mężyk A. Identyfikacja zagrożeń załogi pojazdów specjalnych podczas wybuchu, Wydawnictwo Naukowe Instytutu Technologii Eksploatacji 2012.

8. LS DYNA MANUAL 2010.

9. Patrick L., Kroell C., Mertz H. Forces on the human body in simulated crashes. Proceedings of the 9th Stapp Car Crash Conference. Society of Automotive Engineers. Warrendale 1965.

10. Kopczyński A., Rusiński E., Bezpieczeństwo bierne, pochłanianie energii przez profile cienkościenne. Oficyna Wydawnicza Politechniki Wrocławskiej, Wrocław 2010.

11. Test Methodology for Protection of Vehicle Occupants against Anti-Vehicular Landmine Effects. Wydawnictwo RTO/NATO 2007.

12. Tejszerska D. Świtoński E., Gzik M. Biomechanika narządu ruchu człowieka. Instytut Technologii Eksploatacji PIB 2011. 
13. Wieremieew. J. Miny wczoraj i jutro. Wydawnictwo Współczesna Szkoła Mińsk 2008.

14. Baskin T.W., Holcomb J.B., Bombs, mines, blast, fragmentation, and thermobaric mechanisms of injury, [in] Mahoney F.P., Ryan J.P., Brooks A.J., Schwab C.W.(ed.): Ballistic trauma. A practical guide. Secondo edition, Ó2005 Springer-Verlag London Limited, pp. 45-66.

15. Pryor J.P., Cotton B., Neck Injury. [in] Mahoney F.P., Ryan J.P., Brooks A.J., Schwab C.W.(ed.): Ballistic trauma. A practical guide. Second edition, Ó2005 Springer-Verlag London Limited, pp. 209-240.

\author{
Wiesław BARNAT \\ Faculty of Mechanical Engineering \\ Military University of Technology \\ ul. gen. S. Kaliskiego 2, 00-908 Warszawa, Poland \\ Email: wbarnat@wat.edu.edu.pl
}

